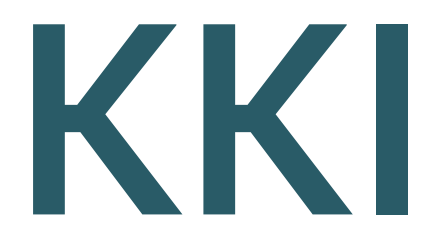

ELEMZÉSEK

Kína mint felemelkedő tengeri hatalom:

a haditengerészet modernizációjának kérdései

China as a Rising Maritime Power:

Issues of Naval Modernisation

\title{
WAGNER PÉTER
}

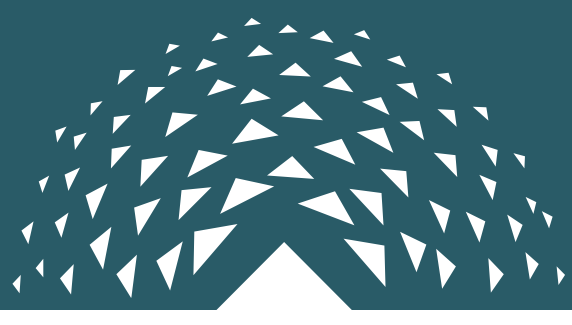




\title{
KKI-elemzések
}

A Külügyi és Külgazdasági Intézet időszaki kiadványa

Kiadó:

Külügyi és Külgazdasági Intézet

Lektorálta:

Baranyi Tamás Péter

Szöveggondozás és tördelés:

Tevelyné Kulcsár Andrea

\author{
A kiadó elérhetősége: \\ H-1016 Budapest, Bérc utca 13-15. \\ Tel.: + $361279-5700$ \\ E-mail: info@ifat.hu \\ http://kki.hu
}

Jelen elemzés és annak következtetései kizárólag a szerző magánvéleményét tükrözik, és nem tekinthetők a Külügyi és Külgazdasági Intézet, a Külgazdasági és Külügyminisztérium, illetve Magyarország Kormánya álláspontjának.

(c) Wagner Péter, 2021

(c) Külügyi és Külgazdasági Intézet, 2021

ISSN 2416-0148

https://doi.org/10.47683/KKIElemzesek.E-2021.05 
Összefoglaló: A 2010-es években Kína nagyhatalmi felemelkedéséneklehettünk tanúi mind politikai és gazdasági, mind katonai értelemben, és ez a folyamat a 2020-as éveket is jellemezni fogja. Peking - az immár tartósan növekvő nemzetközi súlyával összhangban - egyre nagyobb figyelmet fordít az olyan védelempolitikai lépésekre, amelyek célja az Amerikai Egyesült Államokkal való katonai erőegyensúly kialakítása. Ezeknek az erőfeszítéseknek az egyik központi eleme a Kínai Népi Felszabadítási Hadsereg haditengerészetének a mennyiségi és minőségi modernizációja. A jelen írásban ezeket a folyamatokat elemzem.

Kulcsszavak: Kína, Amerikai Egyesült Államok, haditengerészet, haderőmodernizáció, haderőreform, A2/AD

Abstract: In the 2010s, we witnessed the rise of China as a great power, both politically-economically and militarily, and this process will also characterise the 2020s. Beijing, in line with its now steadily growing international weight, is paying increasing attention to defence policy steps aimed at building a military balance of power with the United States of America. One of the central elements of these efforts is the quantitative and qualitative modernisation of the navy of the Chinese People's Liberation Army. In the present paper, I analyse these processes.

Keyword: China, the United States of America, navy, military reform, military modernisation, $A 2 / A D$

\section{BEVEZETő}

A z elmúlt évek során már figyelemmel követhettük a Kína és az Amerikai Egyesült Államok közötti, egyre erősödő hatalmi rivalizálást, és ez a folyamat nagy valószínúséggel ezt az évtizedet is jellemezni fogja. Peking - az egyre növekvő nemzetközi súlyával, valamint a nemzetvédelmi és a külgazdasági érdekeivel összhangban - a 2010-es évektől egyre nagyobb energiát fordít és mind több forrást csoportosít át az olyan védelempolitikai lépésekre, amelyek célja az Amerikai Egyesült Államokkal való katonai erőegyensúly kialakítása.

A nagyhatalmi rivalizálást megelőző időszakban Peking viselkedését Teng Hsziao-ping 1990-ben megfogalmazott, ún. 24 karakteres külpolitikai doktrínája irányította: „Kövessük a folyamatokat nyugodtan, biztosítsuk a pozíciónkat [a nemzetközi térben], rejtsük el a képességeinket, és várjuk ki, amíg eljön a mi időnk, maradjunk kevéssé láthatóak [a nemzetközi rendszerben], és sose törekedjünk vezető szerepre [a nemzetközi kapcsolatokban]."

Kína a prosperáló és stabil nemzetközi rendszerben érdekelt, amely biztosítja az exportorientált fejlődést, amelynek révén a Kínai Kommunista Párt (KKP) a lakosság százmillióit emelhette ki a mélyszegénységből, ezzel megteremtve azt a társadalmi békét, amely kiemelt szerepet játszik a párt hatalmának fenntartásában. 
A tengi külpolitika elveitől a 2010-es években kezdtek eltérni. Hszi Csin-ping megválasztását követően pedig egy ambiciózusabb terv fogalmazódott meg a világpolitikai szerepvállalást illetően. Ehhez kapcsolódott a kínai haderő modernizációjának az új víziója is, amelynek legfontosabb dokumentuma a 2013-as és a 2019-es fehér könyv, illetve a 2015-ös védelmi stratégia.

Az elemzésem tárgyául választott haderőnem, a haditengerészet szerepe 2013tól növekszik markánsabban a kínai stratégiai dokumentumokban, először azonban nem a geopolitikai rivalizálással kapcsolatban kapott nagyobb hangsúlyt. A KKP főtitkára, Hu Csin-tao 2012-ben, a 18. pártkongresszuson az ország további növekedésének egyik kulcsaként szolgáló tengeri erőforrások kiaknázásának a biztosítását tûzte ki célul. A Dél-kínai-tenger alatt „nagyjából 5000 milliárd köbméter földgáz- és 11 milliárd hordónyi olajtartalék található", de az, hogy a szabadon közlekedhessenek a kínai hajók, szintén létkérdés Peking számára. Az amerikai Center for Strategic and International Studies számításai szerint a Covid-járvány előtti időszakban a világ kereskedelmének 21 százaléka haladt keresztül a Dél-kínai-tengeren.

Az elemzés során először röviden bemutatom a hozzáférést gátló, illetve területmegtagadó stratégiát, amelynek részét képezi a Kínai Népi Felszabadítási Hadsereg haditengerészetének (a továbbiakban: a kínai haditengerészetnek) a fejlesztése is. Ezt követően ismertetem a flotta mennyiségi és minőségi jellemzőit, kitérve azok fejlődésére és szerepére is. A hajótípusok esetében a NATO-ban elnevezést használom.

Ezúton köszönöm Trautmann Balázsnak, Matura Tamásnak, Kisvári Tamásnak és Eszterhai Viktornak az elemzés elkészítéséhez nyújtott segítségét.

\section{A KÍNAI HADITENGERÉSZET A MODERNIZÁCIÓ ÚTJÁN}

K ína a történelme során nagyrészt szárazföldi hatalomként defıniálta magát; így volt ez Mao Ce-tung időszakában, a hidegháború alatt is. A bipoláris rend végét követôen a kínai védelmi modernizáció központi kérdésévé vált a korábbi, területvédelmi szempontoktól (azaz a szárazföldi határok védelmétól) az elrettentési és erőkivetítési képességekkel is rendelkező modern haderő irányába történő elmozdulás. Az új tengeri stratégia és a haditengerészeti fejlesztés irányelveinek a lefektetése Liu Hua-csing admirálisnak, a kínai hadiflotta harmadik parancsnokának (1982-1988) a nevéhez fúződik, aki ebbéli minőségében, majd később, a KKP legfelső vezetésének a tagjaként (1989-1997) is kulcsszerepet játszott a ma ismert haditengerészet létrehozásában. Liu három lépcsőben képzelte el a fejlesztést; e szerint a második során Pekingnek képessé kell válnia a közeli tengerek (near seas) birtoklására, a harmadik fázisban pedig a távoli tengereken (far seas) való jelenlétre is. A kínai szakirodalom a Bohai-, a Sárga-, a Kelet-kínai- és a Dél-kínai-tengert, valamint a Tajvan keleti részén lévô óceáni rész jelenti a közeli tengereket, így azok gyakorlatilag lefedik az első szigetlánc (azaz a Kuril-szigetek, Japán, Tajvan, a Fülöp-szigetek és Borneo) által határolt területet. A távoli tengerek pedig kiterjedtebb, 
mint a második szigetláncig (Japán, Mariana-szigetek/Guam, Palau, Nyugat-Pápua) húzódó térség: beletartoznak a Csendes-óceán középső területei, valamint az Indiai-óceán és a dél-atlanti vizek is. Egyes kínai szakértők szerint e folyamatos jelenlét célja, hogy egy kínai-amerikai konfliktus esetére lehetővé tegye a kínai flotta olyan méretú átcsoportosítását, hogy hajók a puszta jelenlétükkel és/vagy a tevékenységükkel lekössék és megosszák az amerikai erőket. Liu admirális fó érdemének azt tartják, hogy a haditengerészeti fejlesztések szükségességét kezdettől fogva öszszekapcsolta a geogazdasági érdekekkel, hiszen megfelelő, korszerú haderő nélkül képtelenség lenne megvalósítani a Dél-kínai-tenger ellenörzését vagy a távolabbi tengeri kereskedelmi utak biztosítását.

A liui stratégia második fázisa megvalósítása során azonban Kínának az Egyesült Államok kelet-ázsiai katonai jelenlétével is számolnia kell. Ennek megfelelően a modernizáció során Peking az aszimmetrikus képességre helyezte a hangsúlyt, azaz a haditengerészeti egységekben és repülőgépekben megmutatkozó amerikai fölényt nem ugyanazokkal kívánta ellensúlyozni, hanem azok megsemmisítését lehetővé tevő fegyverrendszereket (elsősorban rakétákat) állítottak csatasorba ellenük. Ezt a szakirodalom hozzáférést gátló/területmegtagadó (anti-access/area denial, A2/AD) stratégiának nevezi.

1. ábra

Kína jelenlegi A2/AD „buborékja”

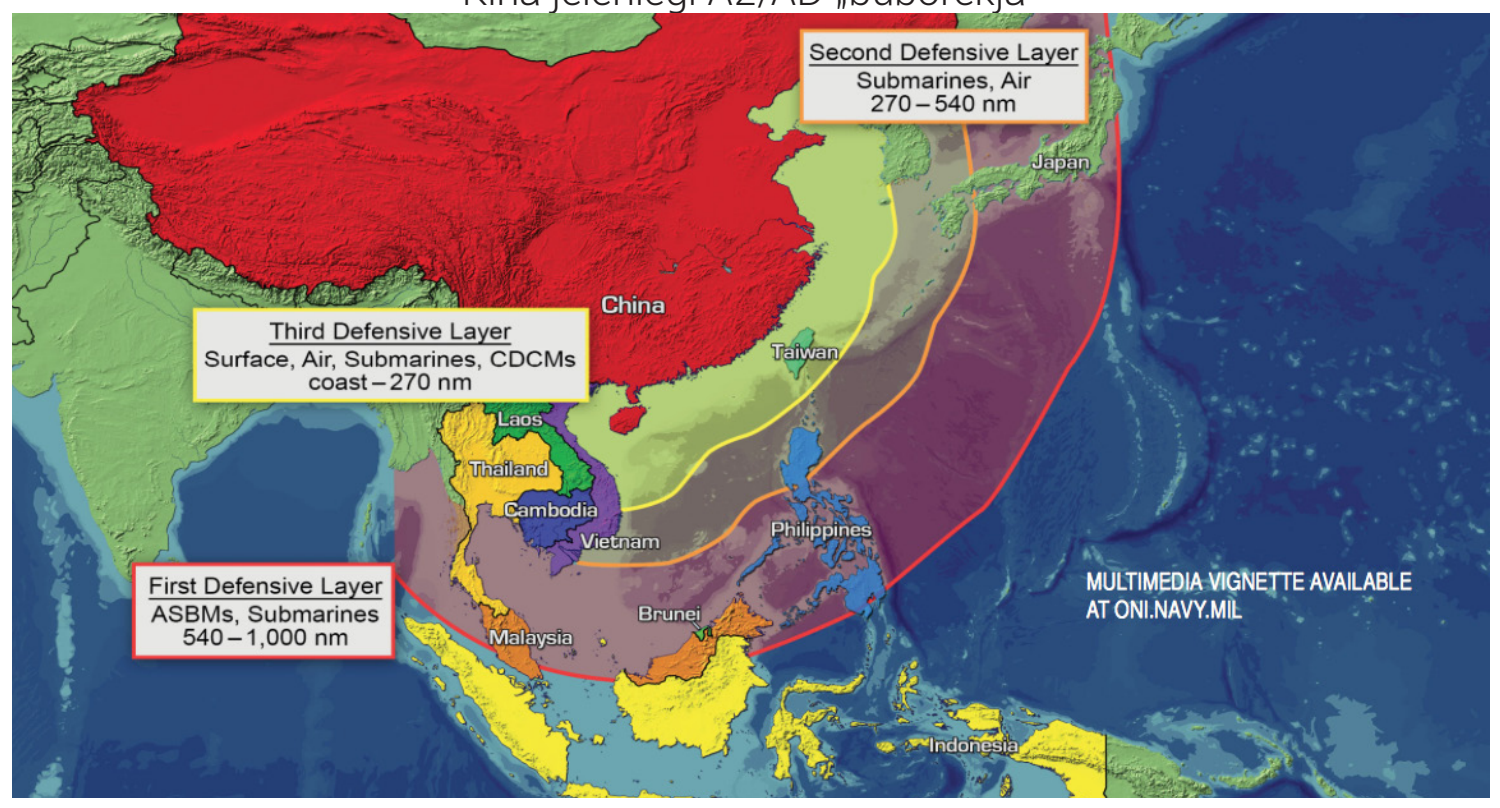

A kínai A2/AD képességeket összességében a haditengerészet mellett légvédelmi rakétarendszerek, hajók elleni ballisztikus rakéták és robotrepülőgépek, valamint a kínai haditengerészet és légierő merev- és forgószárnyas repülőgépekkel felszerelt egységei alkotják. Áttételesen ide sorolható az ország 2013 óta zajló "mesterségessziget-építési" programja is, amelynek keretében a Dél-kínai-tengeren található számos zátonyt és sziklát alakítottak át feltöltéssel szigetté, majd többjükön 
haditengerészeti bázist és katonai célokra is alkalmazható repülőteret építettek ki, amelyeket nagy hatótávolságú felderítő és védelmi rendszerekkel is felszereltek. A Spratly-szigetek hét zátonyán és szikláján például mintegy 12 négyzetkilométernyi területet töltöttek fel, ahol hajók elleni és légvédelmi rakétarendszereket, továbbá különböző kommunikációs, zavaró és felderítő rendszereket telepítettek. Az elemzés további részében a haditengerészetre fogunk koncentrálni.

\section{A HADITENGERÉSZETI MODERNIZÁCIÓ MENNYISÉGI JELLEMZŐI}

K ína számára a már kiépített A2/AD fontos hozadéka, hogy egy, az USA-val esetlegesen kialakuló fegyveres konfliktus során nem kell győzelemre törekednie a Csendes-óceán keleti térségében, elegendő, ha az Egyesült Államoknak túlzottan „költségessé” teszi az intervenció felvállalását. Washington számára előnyt jelentenek ugyan a Kínához közeli - dél-koreai és japán - légibázisok és kikötők, ugyanakkor a két ország is kínai katonai válaszlépéseknek tenné ki magát, s ez jelentősen csökkentheti annak a lehetőségét, hogy egy fegyveres konfliktus esetén engedélyeznék az USA-nak, hogy a területükön levő amerikai bázisokról indítson támadó hadmúveleteket.

A kínai haditengerészeti modernizáció a haditechnikai rendszerek széles körét érinti. A fejlesztések a hadihajókra, a tengeralattjárókra, a repülőgépekre, a távolról irányítható repülőgépekre (UAV), a hadihajók elleni ballisztikus rakétákra és a robotrepülőgépekre, illetve a támogató/kiszolgáló infrastruktúrákra és eszközökre egyaránt kiterjedtek. Az elmúlt évtizedekben modernizálták az e platformok és fegyverek alkalmazását segítő vezetés-irányítási, kommunikációs és felderítő rendszereket (C4ISR), valamint a logisztikát, szabályozást és a kiképzést is. A felsorolásból jól látszik, hogy a kínai erőfeszítések mennyire komplexek és átfogóak, pedig „csak" a haditengerészetről van szó. A többi haderőnem esetében az elmúlt évtizedek fejlődése organikusabb volt, mivel a légierő és a szárazföldi erők korábban is prioritást jelentettek a vezetés számára. Az elemzés a továbbiakban a felsorolt elemek közül a terjedelmi korlátok miatt érdemben csak a köznapi értelemben vett "haditengerészettel”, azaz a hadihajókkal és a tengeralattjárókkal foglalkozik.

A hidegháborút követő időszakba a kínai haditengerészet egy területvédelemre berendezkedett és felszerelt tömeghadsereggel lépett be. A haderőben 1996-ban már 2,9 millió katona szolgált, ám a felszerelésük többnyire hiányos és elavult volt, jobbára az ötvenes-hatvanas évek színvonalát képviselte (így például jelentősen elmaradt a Nyugaton már lezajlott rakétatechnológiai fejlődéstől).

A haditengerészet létszáma mintegy 300 ezer fő volt, de csak 57 darab rombolóval és fregattal rendelkezett, és közülük is mindössze hármat szereltek fel légvédelmi rakétarendszerrel, azaz a haderőnem gyakorlatilag védtelen volt a modernebb riválisok légi támadásaival szemben. A mintegy 80 egységből álló tengeralattjáró-flotta többsége az 1950-es évek színvonalát képviselő, dízel-elektromos meghajtású Type 
033- és Type 035-osztályú hajó volt. Az előbbi a szovjet Romeo-osztály licence alapján, 1962 és 1984 között épült, az utóbbi annak a kínai továbbfejlesztett változata volt.

Az öt egységből álló nukleáris meghajtású vadász-tengeralattjárók 1974-ben léptek hadrendbe (Han-osztály, Type 091), de az első csak az 1980-as években kezdte meg a szolgálatát. Az egyetlen, ballisztikus rakéták hordozására is alkalmas, az Xia-osztályhoz tartozó (Type 092) nukleáris tengeralattjáró 1987-ben lépett hadrendbe; az és a Han-osztályú vadászok meghosszabbított változata volt. Ezek a tengeralattjárók a kor rivális amerikai és orosz egységeihez képest hangosak, technikailag elmaradottak voltak.

A kínai haditengerészet fejlődésében az érdemi változások - először mennyiségi, majd minőségi értelemben - a 2000-es években kezdődtek, és a 2010-es években felgyorsultak: például míg az ország 2005-ben még csak 216 hajóegységgel rendelkezett, 2019-ben már 335-tel. A növekedés első hulláma 2005 és 2009 között zajlott le, amikor is 216-ról 262-re nőtt az egységek száma. A második ugrás 2013-ban kezdődött: az akkor 273 hajót számláló haditengerészet évente mintegy 10 új hajóval bővült. A valóságban ennél több hadihajót építenek a kínai hajógyárak, hiszen a modernizáció részeként az elavult hajóegységeket folyamatosan vonják ki és helyettesítik modernebb típusokkal.

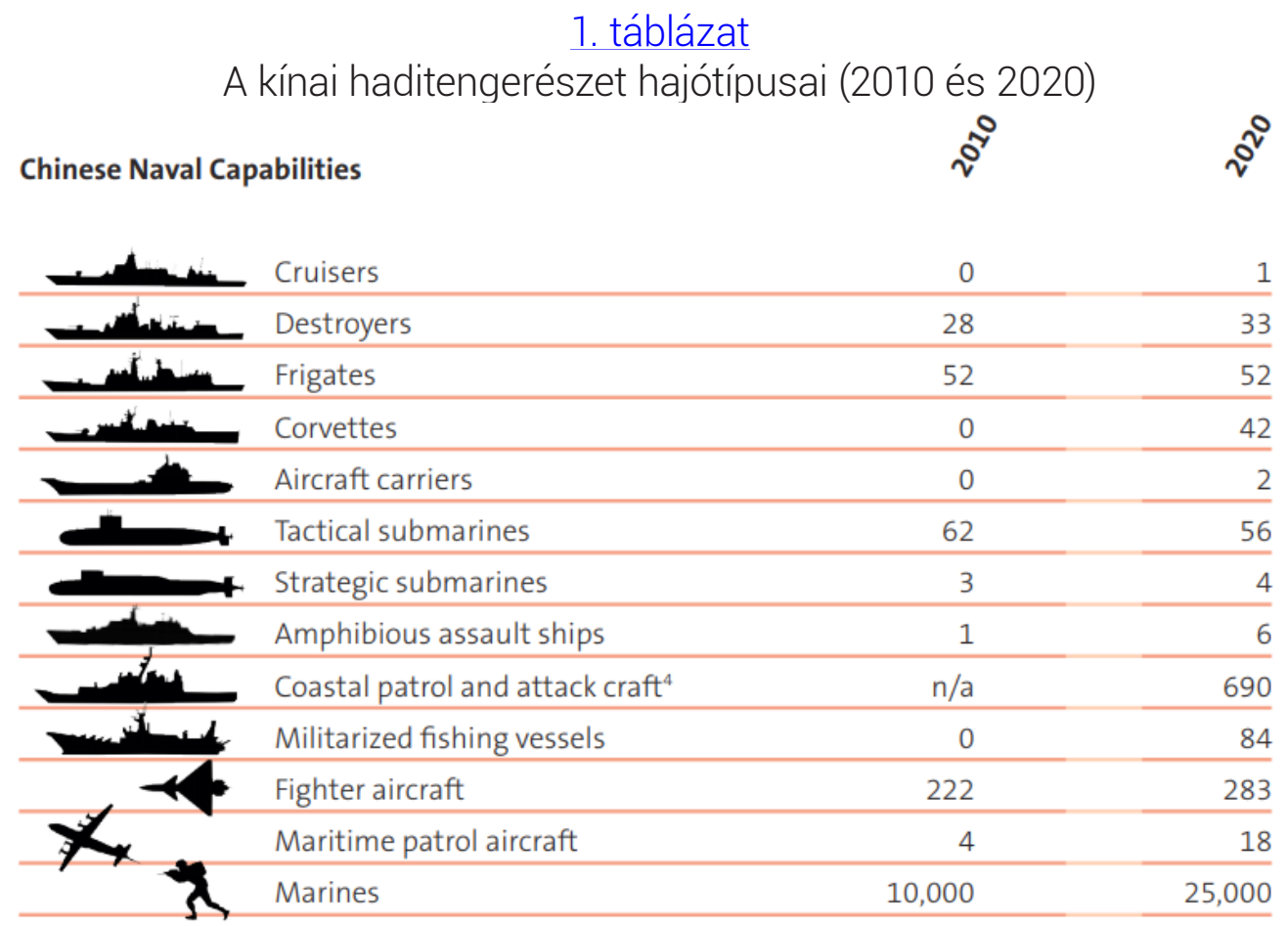

A vízfelszíni és a tenger alatti egységek számát tekintve jelenleg Kína rendelkezik a világ legnagyobb haditengerészetével. Amerikai becslések szerint 2020-ban mintegy 360 hadihajó állt hadrendben, s ezzel jócskán meghaladta a 297 egységet számláló amerikai flottát. Az e tekintetben kialakult erőfölényre még 2015-ben tett 
szert. A kínai hajógyártás lenyűgöző kapacitásait jellemzi, hogy az utolsó három évben (2017 és 2020 között) nyolc Renhai-osztályú (Type 055) és tizenhárom Luyang III-osztályú (Type 052D) rombolót bocsátott vízre, és további több mint hetven Jiandao-osztályú (Type 056/A) korvettet és egyéb hajóegységet szállított le - ezek nem képezik a jelen elemzés tárgyát. 2005 és 2019 között 119 egységgel bővült a kínai haditengerészet, és bár e gyarapodás mintegy 65 százalékát a part menti vizekre optimalizált osztályok tették ki, a flotta így is fontos lépést tett vele ahhoz, hogy elérje azt a kritikus tömeget, amely már az amerikaival szemben is hatékony elrettentő erőt jelenhet, és megteremtheti az erőkivetítés lehetőségét a szárazföldi Kínától távol eső területeken is.

A számok természetesen nem árulnak el mindent a két ország erőviszonyairól. Hiába van kevesebb hajója jelenleg az Egyesült Államoknak, ha azok vízkiszorítása a duplája a kínaiakénak. Azonban azt is figyelembe kell venni, hogy míg Peking a haditengerészetét teljes egészében a Csendes-óceán keleti medencéjére tudja koncentrálni, addig az USA flottáinak két óceánon, valamint a Földközi-tengeren és a Perzsa-öbölben is állandó jelenlétet kell fenntartaniuk.

Amerikai becslések szerint Kína 2025-re 400, 2030-ra 425 egységre bővítheti a hadihajói számát, ami természetesen nem marad válasz nélkül a nagyhatalmi rivális Egyesült Államok, illetve a térségbeli regionális hatalmak, továbbá a Délkínai-tenger körüli viták kapcsán ellenérdekelt szomszéd országok részéről sem. Az USA 2045-re ötszázra növelné a haditengerészeti egységei számát, az ázsiai országok pedig ugyanazon (A2/AD) képességeket fejlesztik, amelyekre eredetileg Peking fektetett kiemelt hangsúlyt az amerikai flotta távoltartása érdekében.

\title{
A HADITENGERÉSZET KÉPESSÉGBŐVÜLÉSÉNEK JELLEMZŐI
}

\begin{abstract}
A kínai haditengerészet stratégiai céljainak a változása jól nyomon követhető az egyes hadihajótípusok mennyiségbeli alakulásából is. A flotta feladata korábban a partközeli vizek védelme volt. Ennek megfelelően a vízfelszíni hajóegységek túlnyomó többségében a fregattok és a korvettek domináltak (s csak kevés volt a nagyobb méretű rombolókból és cirkálókból). A flotta gerincét alkotó Jianghu (Type 053) és Jiangwei I, II (Type 053H2G és H3) osztályok az 1950-es évek szovjet fregattja, a Riga-osztály helyben épített és később - részben nyugati segítséggel - modernizált változatai.

A fregattok a 2000-es évekig „egyfunkciósak" voltak, azaz a fegyverek, radarok és egyéb érzékelő rendszerek komplexitása és méretei miatt a haditengerészeti múveletek széles skáláján csak egy-egy feladatra optimalizálták a fegyverzetüket. E hajókat a korlátozott hatótáv, az elavult fegyverzet és a légvédelmi rakétarendszerek hiánya jellemezte. A Jianghu (Type 053) osztály hajóit alapvetően a vízfelszíni célok ellen szerelték fel, de néhányat légvédelmi feladatokra is alkalmassá tettek, míg például tengeralattjárók elleni hadviselésre csak igen korlátozottan voltak alkalmasak.
\end{abstract}


A fregattok következő generációja, a Jiangkai l-osztály (Type 054) 2005 után lépett szolgálatba. A hajótest és a fegyverrendszerek egy része francia eredetú volt. Ez a hajóosztály, illetve a kínai technológiára támaszkodó továbbfejlesztett változata, a Jiangkai II (Type 054A) már többfeladatú, tehát a tengeralattjárók elleni harc mellett komoly légvédelmi képességgel rendelkezik, és szárazföldi/vízfelszíni célok elleni korlátozott támadásra is képes. A Jiangkai I és II vízkiszorításban is jóval túlszárnyalta a Jianghu-osztályt, így fontos szerepet játszott abban, hogy a kínai haditengerészet megjelenhetett az India-óceánon: Szomália partjainál például a kalózkodás elleni nemzetközi múveletekben vettek részt a kijelölt egységek. Jelenleg a hajóosztály mintegy 32 hajója adja a kínai fregattok túlnyomó többségét.

A rombolók vízkiszorításban és túzerőben is egy kategóriával nagyobbak a fregattoknál. Hagyományos szerepük a nyílt tengeri múveletek során a hajókötelékek vagy a kereskedelmi konvojok kísérése, ritkábban önálló feladatok ellátása. Az 1970 és 1990 között épített Luda (Type 051) osztály rombolóinak alapját az ötvenes években tervezett szovjet Neusztrasimij-osztály konstrukciója jelentette. A típust vízfelszíni célok elleni hadviselésre optimalizálták, hajók elleni irányított rakétafegyverzettel, de csak korlátozott légvédelmi képességgel látták el. Az utolsó egységet csak 2020-ban vonták ki a szolgálatból.

A rombolók fó típusa jelenleg a Luyang I, II, III (Type 052 B, C, D), amelyekból 2019-ben 19 egységet tartott hadrendben a flotta. A típus legmodernebb (C és D) változatai már - a nyugati és az orosz haditengerészetnél is bevett technológiát alkalmazva - a hajótestbe függôlegesen beépített cellákból képesek légvédelmi és hajók elleni irányított rakétákat indítani. Szakértők szerint a Luyang III (Type 054D) az első olyan kínai rombolóosztály, amely a képességek tekintetében is felveheti a versenyt az amerikai vetélytársaival. E szempontból a fegyverrendszerek mellett a típus radarképessége is figyelemre méltó, amely állitólag - az amerikai AEGIS rendszerhez hasonlóan - egyszerre képes a hajókon elhelyezett, bevetésre kész több tucat légvédelmi rakéta számára a célok felderítésére, azonosítására, követésére és az indított rakéták irányítására. (A típus összesen 64 függőleges indítócellával rendelkezik, amelyekből egyaránt lehet légvédelmi és hajó elleni rakétát indítani.)

A Luyang hajóosztály komoly előrelépést jelentett a kínai haditengerészet erőkivetítési képességeiben, és megteremtette annak a lehetőségét, hogy Peking folyamatosan egységeket állomásoztasson olyan távoli múveleti területeken is, mint az Indiai-óceán vagy a Vörös-tenger.

A kínai haditengerészet minőségi továbblépéséhez szükség volt a repülőgéphordozók, a cirkáló méretű rombolók (és az elemzésben nem tárgyalt Type 075-ös, partraszállást támogató hajóosztály) hadrendbe állítására is - ugyanis azok képesek biztosítani azt az erőkivetítési képességet, amelynek révén egy ország az anyakikötőktôl távoli önálló, külső segítség nélkül történő manőverezést, támadó múveletek végrehajtását és önvédelmet lehetővé tevő flottacsoportosítást tud végrehajtani.

A Luyang-osztály kibővített változata a Renhai-osztály (Type 055), amelynek első egységét 2020 januárjában állították hadrendbe, de további hat hajó építése vagy végszerelése zajlik jelenleg. A hajóosztályból összesen 16 darabot rendeltek meg, és elsősorban a repülőgép-hordozók védelmét hivatott biztosítani, s ehhez 
jelentős számú nagy hatótávolságú légvédelmi és vízfelszíni támadó fegyverrel szerelték fel (a hajótestbe 112 függőleges indítócellát építettek be), de képes hajókötelékek vezérhajójaként is tevékenykedni. A Renhai-osztály hivatalosan rombolóként van nyilvántartva de amerikai források gyakran cirkálóként azonosítják. Ennek oka, hogy az osztály egységeinek a vízkiszorítása (bruttó 11.000-13.000 regisztertonna) meghaladja az amerikai Ticonderoga-osztályú cirkálókét, miközben fegyverzete mennyiségileg nagyrészt azonos. Ennek megfelelően az amerikai terminológia cirkálóként említi ezt a kínai hajóosztályt.

Pekingnek a saját repülőgép-hordozó építésére vonatkozó erőfeszítése jól dokumentált. Tanulmányozás céljából korábban egy, a hadrendből már kivont ausztrál, illetve három szovjet hordozót vásároltak meg, ám végül az utolsó, az 1998-ban Ukrajnától beszerzett Varjag cirkáló mellett döntöttek, és azt Liaoning néven (Type 001 hajóosztály) tíz évig elhúzódó újjáépítés és modernizáció után, 2012-ben állították hadrendbe. További négy évet vett igénybe, mire a hordozó elérte a múveletek végrehajtására alkalmas állapotot, a fedélzetén az orosz Szuhoj Szu-33-as vadászbombázó kínai másolataival, a Shenyang J-15-ös vadászbombázó repülőgépekkel.

Kína második hordozója, a Shandong (Type 001A-osztály) 2019 végén állt hadrendbe. Ezt már a Liaoning megépítése során nyert tapasztalatokra építve, saját tervek alapján gyártották. A kialakítása nagyrészt megegyezik az elődjéével, így továbbra sem látták el a nagyobb tömegú gépek indításához szükséges katapultberendezéssel, de kissé nagyobb vízkiszorítású, illetve több repülőgépet és nagyobb mennyiségú üzemanyagot tud magával vinni. Emellett kisebb méretű felépítménnyel, de modernebb vezetés-irányítási és radarrendszerekkel rendelkezik.

2018-ban egy újabb, az előző kettőnél jelentősen nagyobb hordozó építése is megkezdődött. Az egyelőre Type 003-ként emlegetett hajó - ugyanis a Nyugaton használt Type 002 nevet 2019 decemberétől a CV-17 Shangdon viseli - a várakozások szerint 2024-re lép szolgálatba, és minőségi ugrást jelent a Liaoninghez és a Shandonghoz képest, jelentősen növelve az erőkivetítés képességét. A vízkiszorítása 80.000 tonna körüli lesz, s ezzel megközelíti a jelenlegi amerikai hordozóosztályok 100.000 tonnás kiszorítását. Ennél fontosabb, hogy a hajón elhagyják az eddigi "sísánc" kialakítását, és elektromágnes katapultokkal segítik a repülők felszállását. Ez teszi lehetővé, hogy a hordozó nagyobb felszállótömegü repülőket, így komolyabban felfegyverzett vadászgépeket is indítson és fogadjon. A hajóosztályból egyszerre két egység van építés alatt, amelyek közül az első már idén elkészülhet (bár a hadrendbe állításuk akár az évtized közepéig is eltarthat).

A korábbi híradások arról szóltak, hogy Peking megkezdi egy ötödik repülőgéphordozó építését is, amelynek a mérete megegyezne az amerikai hordozókéval, és már nukleáris meghajtású lenne. A Covid-járvány, az ország gazdasági nehézségei és a felmerült technológiai problémák miatt azonban azt egyelőre elhalasztották.

Kína még nincs birtokában minden olyan technológiának, kutatási-fejlesztési képességnek, amely lehetővé tenné, hogy az amerikai repülőgép-hordozókhoz hasonló színvonalú és képességü hajóegységeket építsen. Így például a hajógyárai még nem építettek nukleáris meghajtású vízfelszíni hadihajókat, a repülőfedélzeti üzemeltetés és a hordozókötelékek harceljárásainak begyakorlása és alkalmazása 
még gyerekcipőben jár - éppen erre használják jelenleg is a Liaoninget. De az is elmondható, hogy a hordozókról indítható merevszárnyú repülőgépek képességei szintén jelentős lemaradást mutatnak az amerikai haditengerészettől, különösen a légtérellenőrző repülők, a légi utántöltési képességek vagy az ötödik generációs ("lopakodó") vadászbombázók terén - ezek ugyanis teljes egészében hiányoznak a kínai haditengerészet hadrendjéből.

A kínai tengeralattjáró-flotta ma is elsősorban a partközeli vizekben képes hatékonyan múködni. A hatvan egységet számláló flottából mindössze tíz nukleáris meghajtású, a többi hagyományos, dízel-elektromos üzemú, de a modernizációjuk és a gyártásuk folyamatos. A legmodernebb Yuan-osztályból (Type 039A és B) jelenleg 17 darab van rendszerben, és 2025-ig összesen mintegy 25 egységnek vagy többnek az építését valószínűsíti az amerikai haditengerészet. Az új típus esetén jelentős technikai vívmánynak bizonyult, hogy Peking külső segítség nélkül fejlesztette ki a levegőfüggetlen hajtómúrendszert (air-independent propulsion, AIP), amely ugrásszerúen csökkenti a hagyományos meghajtású tengeralattjárók zajkibocsátását.

Kína a saját fejlesztések mellett az elmúlt évtizedben 12 darab orosz gyártású Kilo-osztályú tengeralattjárót is vásárolt, és évek óta szó van az új Lada-osztály közös továbbfejlesztéséről, például a nagyobb víz alatti hatótávolságot kínáló lítiumion-akkumulátorok alkalmazásáról. Annak ellenére, hogy Oroszországnak jóval nagyobb tapasztalata van tengeralattjárók tervezésében, az olyan technikai újítások, mint az AIP vagy a modern, nagyobb energiasúrúségú és tárolókapacitású akkumulátorok, egyelőre meghaladják az orosz ipar képességeit.

2. táblázat

A kínai tengeralattjáró-flotta számának változása 2000 és 2030 között

\begin{tabular}{|l|c|c|c|c|c|c|c|}
\hline & $\mathbf{2 0 0 0}$ & $\mathbf{2 0 0 5}$ & $\mathbf{2 0 1 0}$ & $\mathbf{2 0 1 5}$ & $\mathbf{2 0 2 0}$ & $\mathbf{2 0 2 5}$ & $\mathbf{2 0 3 0}$ \\
\hline $\begin{array}{l}\text { Ballisztikusrakéta-hordozó } \\
\text { atom-tengeralattjárók }\end{array}$ & 1 & 1 & 3 & 4 & 4 & 6 & 8 \\
\hline $\begin{array}{l}\text { Nukleáris meghajtású } \\
\text { vadász-tengeralattjárók }\end{array}$ & 5 & 4 & 5 & 6 & 7 & 10 & 13 \\
\hline $\begin{array}{l}\text { Diesel-elektromos támadó } \\
\text { vadász-tengeralattjárók }\end{array}$ & 56 & 56 & 48 & 53 & 55 & 55 & 55 \\
\hline Összesen & 62 & 61 & 56 & 63 & 66 & 71 & 76 \\
\hline
\end{tabular}

A nukleáris meghajtású tengeralattjárók új generációi a 2000-es évektől léptek hadrendbe. A nukleáris triád részét képező, egyenként $12 \mathrm{db}$ interkontinentális ballisztikus rakéta hordozására képes Jin-osztályból (Type 094) jelenleg négy van rendszerben, további kettő a végszerelés fázisában. Az ellenséges vízfelszíni flották és tengeralattjárók jelentette veszély elhárítására kifejlesztett új vadász-tengeralattjáró osztály a Shang (Type 093) és utódja, a Shang II (Type 093A) egységei vannak szolgálatban.

Bár a hagyományos meghajtású vadász-tengeralattjárók a hatótávuk és a víz alatti képességeik korlátozottsága miatt elmaradnak a nukleárisaktól, az elmúlt 
évtized fejlesztéseinek köszönhetően mindegyik osztályt felszerelték a torpedóvető csövéból indítható YJ-18B robotrepülőgéppel. Ennek a hatótávolsága amerikai források szerint mintegy $550 \mathrm{~km}$.

A 2. táblázat adatai szerint az elmúlt két évtizedben nem történt érdemi változás a tengeralattjáró-flotta méretében, ugyanakkor a technológiai fejlesztések (meghajtás, robotrepülőgépek, szonárok) révén a fegyvernem képessége sokat javult. Mindezek mellett a kínai nukleáris meghajtású tengeralattjárók a nyilvánosságra került információk szerint - az amerikai, brit és orosz típusokkal összevetve - még mindig a legzajosabbak.

\section{2. ábra}

Egyes nukleáris tengeralattjárók zajkibocsátása és akusztikai felderíthetősége (km-ben)

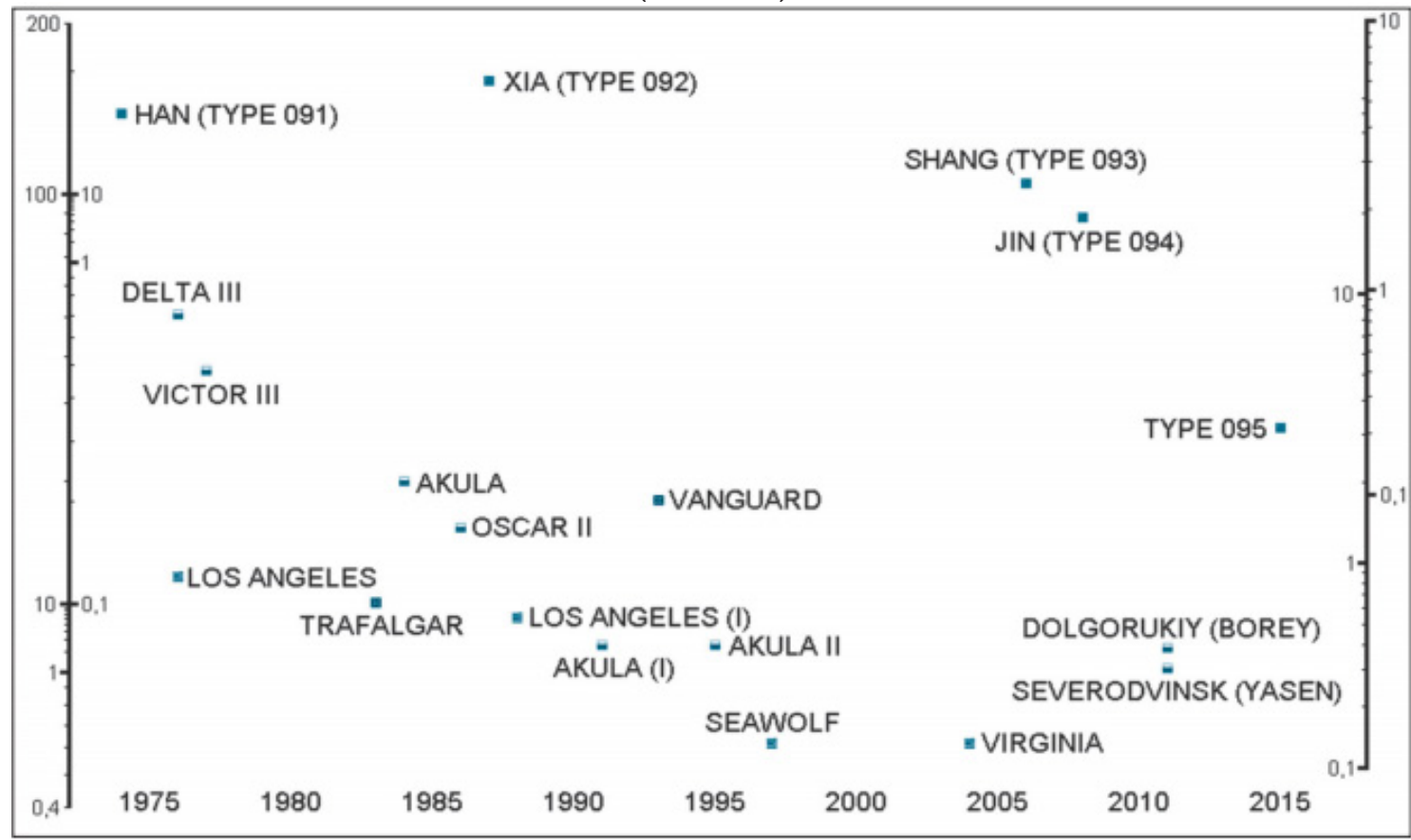

Magyarázat: A bal oldal a mély óceánt, a jobb a sekély vizeket jelöli. „Az egyes skálák bal oldala a legkedvezőbb, jobb oldala a legkedvezőtlenebb körülményeknek felel meg."

Amerikai részrôl éles viták folynak a kínai nukleáris tengeralattjárók jövőbeni trendjeiről. A haditengerészet hírszerzési hivatala szerint további hat egységgel fog nőni a vadászfeladatú hajók száma, s újabb négynek a hadrendbe állításával 2030ra megduplázódik a ballisztikusrakéta-hordozó tengeralattjárók száma. A kérdés megítélése miatt kulcsfontosságú a tengeralattjárót gyártó kapacitások ismerete, mivel jelenleg hagyományos tengeralattjárókat két, nukleárisakat pedig egy hajógyárban építenek. Ez utóbbi a Huludaóban található Bohai Hajógyár, ahol 2015 óta két új csarnokot húztak fel, s ennek köszönhetôen az eddigi egy helyett akár egyszerre négy nukleáris tengeralattjáró építése is történhet. 


\section{KONKLÚZIÓ}

K ína az elmúlt tíz évben nyaktörő sebességgel növelte a haditengerészetét, s ezzel párhuzamosan komoly sikereket ért el a haditechnikai modernizáció terén is. A kínai flotta jelenleg a hadrendbe állított hajók számát tekintve a legnagyobb a világon, és ez még egy évtizedig így is marad. A képességek fejlesztésében azonban még bőven van pótolnivalója annak érdekében, hogy utolérje a világ legmodernebb haditengerészetével rendelkező Egyesült Államokat. A hiányosságok különösen a repülőgép-hordozók (illetve az általuk biztosított képességek) és a nukleáris tengeralattjárók fejletlenségében figyelhető meg, de magában az expedíciós hadviselés terén is évtizedes lemaradások vannak. Ezért a hiteles erőkivetítési képesség kialakítása még hosszú évekbe fog telni, még akkor is, ha sikerül fenntartani a modernizációnak a 2010-es években tapasztalt ütemét. Ezt - figyelembe véve a vírushelyzet okozta globális és így a kínai gazdasági problémákat is - még korai lenne megjósolni.

Tény ugyanakkor az is, hogy Kína számára más az a célrendszer, amelynek részeként alkalmazni akarja a haditengerészetét. Peking szempontjából a flotta elsődleges feladata, hogy a hozzáférést gátló/területmegtagadó stratégia részeként a haditengerészet hozzájáruljon az A2/AD „buboréknak” az első szigetlánctól a másodikig történő kiterjesztéséhez, hogy ezzel logisztikailag is megnehezítse és lelassítsa az amerikai haditengerészet és légierő felvonulását.

Kína még évtizedekre van attól, hogy az Amerikai Egyesült Államokhoz hasonlóan a világ bármely pontján fel tudjon lépni a haditengerészete, a hadászati légiereje és a kiterjedt bázisrendszere révén. Az elmúlt tíz év fejlesztései eredményeként viszont az ország körüli vizeken már sokkal kiegyenlítettebb az erőviszony a két atomnagyhatalom között, főképp a haditengerészet, valamint a kis és közepes hatótávolságú kínai ballisztikus rakéták miatt.

A következő évtizedben a nagyhatalmi versengés folytatódni fog Kína és az Egyesült Államok között: bár nyílt, fegyveres konfrontációra sem rövid, sem középtávon nem kell számítani, a hidegháborús időszakra emlékeztető fegyverkezési versenynek leszünk tanúi, s ebben kiemelt szerepet fognak játszani olyan új technológiák (mesterséges intelligencia, autonóm vezérlésú vagy távolról irányított légi és tengeri jármúvek, stb.), amelyek birtoklásáért amúgy is verseny van a felek között. 